ACTA UNIVERSITATIS LODZIENSIS

FOLIA LITTERARIA POLONICA 8(38) 2016

http://dx.doi.org/10.18778/1505-9057.38.11

Agnieszka Czyżak*

\title{
Rescued Music and Music which Rescues About Wiesław Myśliwski's Treatise on Shelling Beans
}

The narrator of The Horizon thus described friends of his mother, neighbours, Poncki sisters, prostitutes who happened to take him to church.

And when they were singing and their teeth, while they were doing this, shone like ivory, I couldn't resist the impression they were angels and were ascending to heaven and I with them on their angelic wings ${ }^{1}$.

Singing sacred music turns out to be the same act enabling a temporary change, going from the profane zone into the sacred - a unique metamorphose of "fallen women" into "angels". However, the Poncki maidens surrounded themselves with lay music, dance music, at the same time separating them from bleak reality. The narrator recalls after many years:

Tango was in my blood. I have listened to and danced to many tangos since I was very young. [...] My mother always sang tango, being moved by every tango. [...] And above all tango could be heard from Poncki sisters' apartment and we could hear it in our basement, and ad nauseam sometimes even at night ${ }^{2}$.

For Piotr tango, a symbol of dance and passion, eventually became a sign of nonfulfilment. The lost chance of dancing with the beloved person remained a harbinger of future disappointments and life disasters. The author of Horizon remained permanently deaf to sacred music, preferring to watch Anna play to it, and the anticipation of his fiancée's touch made it impossible to hear and understand the sounds in melodies played by church organs. Meanwhile, in his next work, Shelling Beans, the main character is immersed in the sphere of music, having an innate addiction to it and having it as the centre of his existential, philosophical and metaphysical considerations.

* Dr hab. prof. UAM, Adam Mickiewicz University in Poznań, Department of Poetry and Literary Criticism; e-mail: agnieszkaczy@tlen.pl

${ }^{1}$ W. Myśliwski, Widnokrag, Muza, Warsaw 1996, p. 288.

${ }^{2}$ Ibidem, p. 456. 
Seweryna Wysłouch stated:

Myśliwski's monologues are becoming more and more sophisticated, more accurate, more philosophical, "wiser". But simultaneously a protest is submitted against the inflation of words that can be born in an uncontrolled way ${ }^{3}$.

Words are therefore not only suspected by Myśliwski but a more difficult task turns out to be engaging in a continuous struggle over their proper usage, composition, putting them together and counterpoint colliding so as to extract even a transient harmony, order and sense from them. In this way, a biography of the protagonist told many times in different variants (variations), thus describing in various tones of the style "existence - non-existence" - eluding unambiguous ontological attributing - writes itself in philosophical considerations about the essence of being.

Ewa Wiegandt wrote about connections of Myśliwski's last novel with a tradition of treatise writing:

Myśliwski's novels belong to this kind of texts that demand repeated reading. One can detect marks of a treatise that one does not read but study, that has a thematic instead of feature order. But "thematic" composing connected with turning prose into essays, its so called leitmotif and counterpoint composition are above all indications of a modern novel ${ }^{4}$.

Treatise on Shelling Beans simulates a chronological and chaotic arrangement of incoming and disordered recollections and remains above all a precisely composed and consciously ordered modern novel in which musicality - functioning on the level of topic, plot and composition - determines an extremely important dimension of interpretation. In the first chapter of Treatise on Shelling Beans, in one of the initial paragraphs of this several-page-long monologue spoken in the presence of a mysterious visitor, the narrator quickly emphasizes his

${ }^{3}$ S. Wysłouch, Twórczość Wiesława Myśliwskiego wyzwaniem dla badacza literatury, in: O twórczości Wiesława Myśliwskiego, vol. II, J. Pacławski (ed.), Kieleckie Towarzystwo Naukowe, Kielce 2007, p. 32-33. The researcher thus ends her consideriation: "Myśliwski's creative output introduces us into the central problems of modern literary science: dilemmas of the historicalliterary synthesis, interpretation, new historicism, anthropology of literature, subjectivity. And provokes to broader literary reflexion" (ibidem, p. 34).

${ }^{4}$ E. Wiegandt, Powieściowe traktaty Wiesława Myśliwskiego, in: O twórczości Wiesława Myśliwskiego, vol. II, pp. 61-62. The author states further: "musical composition of Myśliwski's prose (music is also one of the topic and feature plots) has two culminating moments: Pałac and Traktat... In these two works the imposing of compositional-rhetorical network on the seemingly chaotic element of a dialogized monologue is the most sophisticated and mimetic in relation to analogous laws of speech, memory, narration." 
existential situation: "I can do nearly everything. I only can't play the saxophone. But yes, I used to do it." "The inability to play the instrument, a concealed suffering caused by losing the sense of being comprehended as the ability of "being to music", returns in every scene of the biography that he reproduces for himself, in every chapter of the biography, because on every occasion the speaker feels the compulsion to identify himself as the one who used to play all his life but does not do it anymore. This owner of three saxophones, a soprano, an alto and a tenor as well as of a flute and a clarinet can only look at the instruments, touch them and by strength of his imagination play the pieces he once performed in silence. The non-resonant music he and rescued dogs can only hear has an invariable (at the autumn of his life as well as in his youth) power to drown the noise of painful memories and soothing wounds - traces of evil inflicted. Simultaneously, listening to the music played by others becomes for the narrator an escape from everyday life, immersed in an outer world, clearly separated from surrounding reality. He confides to his listener:

One evening, in late autumn, after the season, I was listening to music. When I listen to music I usually don't turn on the lights. Suddenly I heard as if someone drove up in a car on the other shore. You know, I can listen to music and still can hear everything (p. 26).

Listening to music becomes a kind of mystery, conducted in darkness and solitude and simultaneously a different form of being, an existence parallel to everyday life filled with mundane obligations. Every act of communing with music is touching the mystery of existence for the hero. This aspect of consideration returns repeatedly in the time of the monologue, performing partially also a function of a pre-death confession, being also shown directly: "In my opinion nothing fraternizes life and death as much as music. Please believe me, I have played all my life, I know" (p. 85). The knowledge of its both transgressive and transcendental character gained by years of communing with music is a wisdom that enables further existence. The beginning of the road to learning music was playing a mouth organ given by an uncle who later committed suicide. At first it seemed a way to chase away boredom pestering a rural old man, compelled to spend whole days in the pasture. However, it quickly changed into a greedy and nearly compulsive extracting of all possible sounds, playing all the time and in every possible place, even in the privy. The musical kindergarten ended with knowing all the secrets of this first musical instrument. Uncle John said prophetically:

${ }^{5}$ W. Myśliwski, Traktat o tuskaniu fasoli, Znak, Cracow 2006, p. 7. In the case of additional quotations coming from this work I will give the page number related to the specific publication. 
Oh, you won't be using this mouth organ for a long time. Choose the saxophone next. Nobody saw a saxophone here, so they will ask you to play at all parties, wedding parties. And maybe somewhere else, somewhere farther and higher. The saxophone is all the rage now. And the saxophone means the world. [...] The saxophone must come so that something changes. Maybe then they will start dancing differently and live differently (p. 87).

The saxophone, once seen by the uncle on an exhibition, was too expensive, and recognized too late as a pass to a possibly acceptable career, appears as a necessary element of his nephew's future, his chance and hope to change his fate. To do so the project of selling land is proposed - which is especially extraordinary taking into consideration rural traditions - to buy the dream instrument. All dreams - these concerning the future of a talented child and a better future of the world where saxophone music would be resounding too - were brutally destroyed by WWII. The time of war - a time of gunshot booms and the dead silence of wastelands - left the world and surviving people irretrievably mutilated. In the post war world, at Voluntary Work Service (OHP) school, war orphans, taken there more than once against their will, experienced suffering over the measures of a child's mind using instruments that were equally orphaned and smashed by war.

An image that remained in the hero's memory was:

a day room that took up the whole barrack was buried with musical instruments. [...] Trumpets, flutes, trombones, bassoons, clarinets, violins, violas, cellos, double basses. There were even instruments that our music teacher had just shown us, when they had finally brought him. There was also a saxophone, an alto one. As a matter of fact, two of his keys were missing but you could set your fingers to the holes and managed to play. Some instruments were in even worse condition. Twisted out of shape, smashed, breached, with holes from bullets, shrapnel as if they took part in the war too (p. 87).

The narrator recalling the instruments "presumably confiscated from the oppressors, bloodsuckers, exploiters and other riff-raff" (p. 96) reminds himself both of the common indifference to useless objects among the pupils as well as their desire to know them. The most wounded of all the school day room instruments were a harp, a harpsichord and viola da gamba, an appropriate place for which would have been a museum. The first music teacher, who was an alcoholic destroyed by war, was crying over the instruments. In his soul, the suffering of instruments, their defenselessness and innocence personified the lost innocence of man and the world. Probably in his previous life a conductor and composer in post-WWII Poland he was compelled to offering music lessons to the reluctant people under his charge and delude himself with a vision of forming an orchestra out of them. He used to drown his miseries in alcohol. It was only when he was playing that his hands remained "sober", able to reconstruct precisely music 
learnt before the war. During one of the pupils' rebellions, when the teacher was nearly hanged by them, he managed to make a mute orchestra out of them and conduct it in an appalling silence:

there was no music to be heard. His hands were the only music. And as we couldn't hear it it was of no importance! He heard it for sure. He needed us only so that he could hear what he wanted to (p. 135).

When he was being taken away in an unknown direction in the Security Service car his pupils - the same ones who previously wanted to hang him - arranged themselves awkwardly in a not-so-well-remembered shape of an orchestra and he shouted in the last moment: "Long live music!". This teacher, being able to hear music of the Absolute even in silence, and in clumsy attempts with a talented pupil, convinced the hero to dedicate himself to the violin. He often repeated: "You have heart for the violin. You have a soul for the violin. You are a good boy. You will be kinder to God because of the violin" (p. 95). Whereas God, indifferent to the fate of this world and helpless against human crimes:

if he even listens to something, then it can only be the violin. The violin is a God's instrument. He no longer listens to words, He wouldn't be able to. There are too many of them. And in too many languages $[\ldots]$ in the violin there are words of all languages, all worlds, this world, other world, life, death (p. 96).

The present-day Tower of Babel, existing not against God but in spite of Him, turns out to be a clamour of human complaints, requests and maledictions that are impossible to listen to, hear and understand by The Almighty. The only sphere where harmony is is able to move The Absolute was music. An old organist whom the Hero randomly met and whom he helped to retrieve destroyed organs from the ruins of a church had similar thoughts - the old man used to say: "God is music and only after that an omnipotence" (p. 221).

Fernand Braudel, writing of civilizations as continuously forming "collective mentalities" stated:

Every civilization continuously picks in the mass of goods and views that are proposed by its past and the road covered. It aims, hesitates, rejects or preserves. In the process of these continuous choices it composes its face, new, and still the same. "Internal refusal" can be firm, gentle, long-term or fleeting. It grows in value, especially, when it is conscious and repeats itself $f^{6}$.

\footnotetext{
${ }^{6}$ F. Braudel, Gramatyka cywilizacji, transl. H. Igalson-Tygielska, Oficyna Naukowa, Warsaw
} 2006, p. 64. 
A civilization described by Myśliwski refused to understand reasons for the catastrophe that destroyed the known order of the world. The author, showing, above all, the victims of the cataclysm and even the former oppressors as its victims refused to acknowledge the truism of evil that is invariably in the human nature as the real cause of the fall of civilization, sketching portraits of castaways of the historical storm with deep empathy. The present - chaotic, not in order, inconceivable - reflects the memory chaos of individual experiences, words can only serve as attempts to describe the shards of individual fate, unable not only to synthesize historical transformations but to diagnose collective experience as well.

The narrator avoids speaking straight stating only:

it was only after the war that it turned out what this war had been, what a great loss not only of the human being but also of God. It seemed that man would never raise, that he exceeded his measure and God did not prove his existence (p. 363).

The helplessness of words and the inability of languages to close experiences in the boundaries that result, makes us search for a sphere able to recreate the lost order of the world. Bogumiła Kaniewska, writing of the means of creating mythical reality in Myśliwski's previous works, of building opposition between an ordered "first world" of the childhood and a destructive historical experience, stated:

Myśliwski cares not about outlining a certain cutting of the world (understood geographically) but about observing a certain type of experience of reality - dependent not on geographical but cultural motherland [...]. It is a reality "tamed" by the experience of the predecessors, the reality, in which everything has a strictly defined place - and so does the human being too ${ }^{7}$.

However, in Treatise ... the memory of the past had no creative potency. It was a faint memory of the old order, smashed irrecoverably from the earth's crust; immobilized in memory as a dead picture that a survivor has no real access to. It remained not as a treasury of living traditions but a reminder of one's beginning lying in an individual past. Closing with a solitary conducting of memory rituals, the persistent showing of epitaphs is a gesture that partly satisfies the desire to organise the world anticipating the prospective end.

The hero speaks with full conviction:

not only music but life itself is governed by rhythm. When man loses rhythms in himself, he also loses hope. What is crying, what is despair, if not a lack of rhythm. What is memory if not rhythm (p. 98).

\footnotetext{
${ }^{7}$ B. Kaniewska, Wiesław Myśliwski, Dom Wydawniczy Rebis, Poznań 1995, p. 126.
} 
It should be addended - a singular rhythm, made in the solitude of remembering fleeting details from a biography that is devoid of sense. After the catastrophe of the civilization, the only one that remained of his family and home village, he can find a specific, substitutive sense of existence only in the escape from his birth place into the world that is not associated directly with own experience in which an effective aperture separating him from the suffering caused by memory turns out to be music.

The hero learnt to play all instruments, however it was the saxophone that cured him, enabled him to come back to life, find hope, arouse a willingness to be born again. The ability to play gave also birth to the will of having a saxophone - a material link with the sphere of music. The hero "in the mildest months" saved, denied himself pleasures and put aside all the money, which he was hiding in his straw mattress and counted many times, for the instrument. But a post-WWIIexchange of money created another catastrophe - making it impossible to buy his dream saxophone, denying him simultaneously a symbolic sign, and a found purpose of existence. The narrator stated unambiguously: "The only thing that I felt was that I had nothing to live for. And I decided to hang myself" (p. 109). The hero was saved from death by the ghost of uncle John, who thus summed up his transcendental experience: "I hanged myself and I see no difference" (p. 110), thus leveling the forms of existence at the both sides of an ultimate end and eliminating indirectly the very border of existence itself. A few years after these dramatic events music reemerged in the life of an electrician, devoid of any higher hopes and aspirations. A new teacher - in fact a warehouse attendant damaged by the war - a saxophonist by trade and spirit, did not protest against the choice of instrument and even convinced him to take his own. He wanted - in return for this - only to teach the hero really well so that in developing his technique he would comprehend the essence of reaching authentic feelings by means of music.

He urged him repeatedly:

If you want the saxophone to fraternize with you like soul and flesh, you must open yourself to it too. You won't hide anything from it and it won't hide anything from you. And every time you hit the wrong note it will jam and won't allow any more freedom. [...] You must play with all yourself with your pain, your cry, your laughter, hopes, dreams, everything that is in you, all your life. Because all of this is music. You are the music, not the saxophone (p. 195).

At the same time a statement: "You are music" meant in fact "you are", "you exist" - bringing a new dimension of saving. The pupil understood at last that a saxophone must become "sensitive as pain" so that the strangeness between it and a player could be overcome, and in this way, find a way to remove pain from the soul by means of an instrument and music played on it. 
The ability - technically polished - to play for everyone who pays for dancing made the hero wander through hotels and dance halls of Western Europe ${ }^{8}$, until an illness made it impossible for him to play and didn't allow the wanderer to return to his homeland. Good money was not the only gratification for artistry - playing for dancing was for our hero a way of discovering the normal dimensions of life, knowing (or rather observing) people and their nature. He was explaining to his patient listener: "As you know hardly anyone listens to classical music and everyone wants to dance". He also added "It is only in dancing when it is best visible who is who" and summarizing this part of his biography: "If I hadn't played for dancing, I wouldn't know people so well"' (p. 366).

At the end of his life he had a dream of the soul of the saxophone player to reach Absolute by means of music. Unable to play, he had to admit the mystical power of silence:

"Sometimes I think that if someone could play silence it would be make THE music. [...] Saxophone is not such a music. I do not regret that I did not devote myself to any other instrument. For example to violin as that school teacher was coaxing me into. It started this way and stayed this way. Apart from this I played for dancing as you know. But let's say nothing about it as I don't play anymore" (p. 362).

In the silence of the lost gift of playing, in the darkness of night thinking there was born a longing to cross the boundaries of knowledge. Rudolf Otto wrote at the beginning of the $20^{\text {th }}$ century: "That which is noble, what is magical, is - as much as possible - only a direct means of showing numinous in art". There are only two direct means and "they are characteristically negative only, these are darkness and silence."

Otto also added: "In the language of sounds it is only silence that answers darkness" $"$. And it is exactly silence in darkness that leads the hero to a deep sacred experience at the end of his life.

The previous choice of music - "lay" and not "sacred" - determined the fate of the hero for many years. However, after his war experiences this choice was obvious and understandable as a gesture of declaring oneself on the side of life. The saxophone, in addition to enabling one to "cross the boundary in oneself"

\footnotetext{
${ }^{8}$ Writings of the hero's life can be read as another literary re-narration of the Odysseus myth, a wanderer coming back home - to the place of his birth - after years of voyage. Saxophone music - in this take would be identical with mermaids singing and luring sailors to dangerous depths, a beautiful but dangerous delusion. Cf. A. Czyżak, Zapomnieć zagładę Itaki, in: O twórczości Wiestawa Myśliwskiego, Vol. II, op. cit.

${ }^{9}$ R. Otto, Środki wyrazu "numinosum”, transl. B. Kupis, in: Antropologia słowa, G. Godlewski (ed.), Wydawnictwo UW, Warsaw 2003, p. 319.

${ }^{10}$ Ibidem.
} 
made it easier to free oneself from the excess of traumatic experiences. Music could only be manifested at the end of his life as a sphere free of sacrum, not common, free of the stain of human history, both the clear and purifying universe free of all composed melodies, able to reach the soul of a listener and co-create it, get through protective barriers and eliminate them, reach human inner-feelings and point the way to understanding one's own fate. Because music - by opening memory - opens the way to self-understanding and determining the human condition in the smashed world order. The hero stated unambiguously, determining the boundaries of knowledge: "I am listened to myself, my soul is listened, as if I could not realize it was me?" (p. 376).

Ewa Wigandt studying the role of music in Treatise on Shelling Beans came to the conclusion that playing each instrument "engages concrete body and soul, being an equivalent of epiphany". Music, in addition, in this work:

was brought into the problem of silence equivalent to spirituality. A silent school orchestra, instruments smashed by war and people listening to an inner voice ${ }^{11}$.

The inner voice, characterized by ethics, is the voice of objection against the decline of the communal tradition and thus serving to rebuild its fragments - although only in a singular dimension - and inscribing the spirituality of individual humans into a sphere of pursuit of a destination, which is a continually renewed gesture of bestowing a sense to existence.

In Myśliwski's work a voice of inner orders, silence towards the world and omnipresent music co-create a vision of rhythmical repetition of an individual gesture of recreation of lost, discarded meanings.

Therefore, music, according to Myśliwski, is able to replace words devoid of salutatory dimension and is even made to replace them in finding partial harmony in the relations of man with his own existence, marked by pain, suffering and death. Myśliwski's novel spread between aspiration to precision of recognition and the bitter knowledge of inexpressibleness of existence finds itself in subjecting the peculiarity of music and aspiration to musical methods of the text ${ }^{12}$, as a way to cross boundaries of art of words.

However, in order to justify the claims of similarities between Myśliwski's prose and concrete musical genre - against difficulties resulting from divergence of material - then the choice would have to be late romantic adagio pieces.

${ }^{11}$ E. Wiegandt, op. cit., p. 72.

${ }^{12}$ Recognizing the importance of obvious restrictions of art correspondence resulting above all from variety of material (see M. Głowiński, Literackość muzyki - muzyczność literatury, in: Muzyka w literaturze, A. Hejmej (ed.), Universitas, Cracow 2002, pp. 101-121) clearly signaled the creator's intention cannot be omitted as he pursues to create an illusion of "musicality of literature" - comprehended not as a theoretical reflection but an element of poetics of an own text, co-creating its meaning. 
Discovering epistemological similarity and theological features chosen to describe the end - of man and the world, leads to the discovery of surprising similarities in the strategies of Deception, caused by both, reading Myśliwski's novel, and listening to late pieces of eminent creators of the nineteenth century music.

Bohdan Pociej in his consideration of this late style in music stated:

Late romantic style masters - Wagner - Bruckner - Mahler - music attains state - let's call it wisdom (in Biblical and philosophical sense); in other words: state of higher conscience - in adagio stage, in adagio. And this means that it can be translated - lectured - interpreted - symbolically (metaphysically, ontologically) and theologically ${ }^{13}$.

Pociej claimed that the music of adagio "is born, created, expands itself as a manifestation and symbol of two polar opposite states: aspiration and duration". The composer thus "demonstrates and exposes a dynamic process of formation and development of music" but in adagio "this movement dynamics is characteristically slowed; the form of music becomes un-dynamised"14. Therefore, a vision of the second adagio extreme is crystallized, duration - "a secretive, mysterious phase of music in which as if in a magical transformation, time (pure one) is identified with space"15. It can be acknowledged that it is - in music - a vision of victory over the passing.

Ewa Wiegandt in her recognition of the problems of musicality in regard to the twentieth century prose stated that music is above all:

a sign of a certain aesthetic ideal which an idea is comprised of autothematicity and autonomy of art and the idea of overcoming limitations of own material. It is not a coincidence that music as an art that is autotelic to the maximum synonymizes art in general. [...] dialogue relations are also possible between forms of different art disciplines, and every two-voiced utterance informs not only of its subject but also of itself. It has thus the metatextual dimension. 'Musicality', 'sculpturity', 'paintivity' of a literary work tells us more of literature than of art it pursues ${ }^{16}$.

${ }^{13}$ B. Pociej, Późny styl: Wagner - Bruckner - Mahler, in: Styl późny w muzyce, literaturze $i$ kulturze, W. Kalaga, E. Knapik (eds.), Wydawnictwo "Śląsk", Katowice 2002, p. 104.

${ }^{14}$ Ibidem, p. 104. The author claimed: "this form - for great masters - is characterised by a peculiar charm, being eloquent. When adagio delves into us and our full attention is focused on it, then in its adagio movement - as a symbol of aspiration - wandering - searching - is revealed to us in another deeper sense: aspiration to cross the boundaries that are natural for the human condition. What is explained symbolically: as an expression of spiritual desires and longings that are natural for human beings: transcending from own being, own existence and condition; also maybe: overcoming the sense of determining own fate".

${ }^{15}$ Ibidem, p. 105.

${ }^{16}$ E. Wiegandt, Problem tzw. muzyczności prozy powieściowej XX wieku, in: Muzyka w literaturze, p. 77. 
The musicality of Treatise on Shelling Beans results from the author's literary diagnosis and co-creates it simultaneously. In the $21^{\text {st }}$ century music became a symbol of cultural duration, a cement between generations, this part of tradition that remains resistant to degradation. One of the supporting characters of the novel, an eccentric hat seller, expressed it clearly:

When words are futile, thoughts are futile, and imagination does not want to imagine anything anymore, it is only music that remains. Only music for this world, for this life (p. 331).

In Myśliwski's novel the end of logocentrism articulated on different levels of the work combined nevertheless with certainty that it can be expressed in words only. The conviction that only music - this universal art, timeless - saved from the historic catastrophe can have a salutatory value, gains its moving expression in the composed beauty of word art. Music, being a substitute of order and harmony, must be therefore described so that it gains a dimension of philosophical being and crosses the stereotype of "an ornament", "triviality", fleeting "pleasure" - useless and in fact redundant in everyday life.

As the narrator of Mysliwski's novel convinced us if someone has got a gift of listening and a grace of hearing, then by means of music one can find a difficult way to agree with the cruel disorder of existence. However, someone must put this bitter knowledge within the confines of a text that is conscious of its limitations but acknowledging its duties of aspiration to the truth (artistic and existential), to show the way to those who are deaf to the salutatory power of music.

\section{Bibliography}

Braudel Fernand, Gramatyka cywilizacji, transl. H. Igalson-Tygielska, Oficyna Naukowa, Warsaw 2006.

Czyżak Agnieszka, Zapomnieć zagładę Itaki, in: O twórczości Wiesława Myśliwskiego, Vol. II, Jan Pacławski (ed.), Kileckie Towarzystwo Naukowe, Kielce 2007, pp. 157-182.

Głowiński Michał, Literackość muzyki - muzyczność literatury, in: Muzyka w literaturze Antologia polskich studiów powojennych, Andrzej Hejmej (ed.), Universitas, Cracow 2002, pp. 101-121.

Kaniewska Bogumiła, Wiesław Myśliwski, Dom Wydawniczy Rebis. Poznań 1995.

Myśliwski Wiesław, Traktat o tuskaniu fasoli, Znak, Cracow 2006.

Myśliwski Wiesław, Widnokrag, Muza, Warsaw 1996.

Pociej Bohhdan, Późny styl: Wagner-Bruckner-Mahler, in: Styl późny w muzyce, literaturze $i$ kulturze, Wojciech Kalaga, Eugeniusz Knapik (eds.), Wydawnictwo "Śląsk", Katowice 2002.

Wiegandt Ewa, Powieściowe traktaty Wiesława Myśliwskiego, in: O twórczości Wiesława Myśliwskiego, Jan Pacławski (ed.), Kieleckie Towarzystwo Naukowe, Kielce 2007, pp. 75-90. 
Wiegandt Ewa, Problem tzw. muzyczności prozy powieściowej XX wieku, in: Muzyka w literaturze, Muzyka w literaturze Antologia polskich studiów powojennych, Andrzej Hejmej (ed.), Universitas, Cracow 2002, pp. 313-336.

Wysłouch Seweryna, Twórczość Wiesława Myśliwskiego wyzwaniem dla badacza literatury, in:

O twórczości Wiesława Myśliwskiego, vol. II, Jan Pacławski (ed.), Kieleckie Towarzystwo Naukowe, Kielce 2007, pp. 35-56.

\section{Agnieszka Czyżak}

\section{Rescued Music and Music which Rescues. About Wiesław Myśliwski's \\ Treatise on Shelling Beans}

\section{(Summary)}

The article focuses on the interpretation of the last novel written by Wiesław Myśliwski: Treatise on Shelling Beans (Traktat o tuskaniu fasoli). The author presents a biography of the hero - a musician and homo viator. The novel describes his life and its connections with Polish history in the $20^{\text {th }}$ century. Above all, it presents reflections on the role of music in culture after World War II. In his Treatise on Shelling Beans Myśliwski performs anti-logocentric turn - music is created as a sphere of art which has a/the power of salvation: it could save a human life from destruction and could stop the destruction of rudimental senses which formed European culture.

Keywords: Wiesław Myśliwski, Treatise on Shelling Beans 